\title{
El origen del sistema bibliotecario español: características y utilidad de los fondos bibliográficos que conformaron las primeras bibliotecas públicas en el segundo tercio del siglo XIX
}

Genaro Luis García López*

Artículo recibido:

25 de septiembre de 2014.

Artículo aceptado:

9 de junio de 2015.

\section{RESUMEN}

Se presenta un análisis histórico del sistema bibliotecario liberal en España durante el segundo tercio del siglo XIX. Se estudian las características del fondo bibliográfico, las distintas funciones de las bibliotecas provinciales y la utilidad que tenían estos centros en la sociedad; finalmente se esboza una tipología bibliotecaria que fue el resultado de la política que realmente se llevó a cabo, lastrada por las distintas carencias inherentes a los problemas asociados a la misma. Se concluye que los medios disponibles no eran los adecuados para conseguir los objetivos inicialmente planteados, por lo que los centros creados no se ajustaban

* Universidad de Salamanca, España. genaroluis@usal.es

INVESTIGACIÓN BIBLIOTECOLÓGICA, Vol.30, Núm.69, mayo/agosto, 2016, México, ISSN: 0187-358X. pp. 231-262 
por completo a las funciones que se habían previsto sirviendo como depósitos del patrimonio cultural más que como centros activos de lectura.

Palabras clave: Sistema Bibliotecario; Política Bibliotecaria; Bibliotecas Públicas Provinciales; España; Siglo XIX.

\section{Abstract}

The origins of the Spanish library system: features and usefulness of the bibliographic holdings of the first public libraries in the middle decades of the nineteenth century

Genaro Luis García-López

The study offers a historical analysis of the liberal library system in Spain during the middle decades of the nineteenth century, while describing the library holdings, the diverse functions of provincial libraries and their usefulness to society. Finally, we outline the typology of the library that arose from policies hampered by various inherent shortcomings. We conclude that the resources available were insufficient to achieve stated objectives, resulting in deployment of centers that resembled depositories of cultural heritage, rather than places for reading.

Keywords: Library System; Library Policy; Provincial Public Libraries; Spain; Nineteenth Century.

\section{INTRODUCCIÓN}

En n este artículo se pretende identificar las principales funciones de la biblioteca pública en el periodo analizado, apuntar las principales características del fondo bibliográfico que debía conformar las bibliotecas provinciales y poner de manifiesto las incongruencias existentes en el modelo liberal español.

La metodología seguida en este estudio ha consistido en identificar las fuentes que permitirían desarrollar los objetivos propuestos, a partir del co- 
nocimiento que los autores tenían de ellas con base en investigaciones previas sobre periodos históricos próximos, localizando la documentación pertinente en diversos archivos. Dicha documentación, original e inédita, refleja el funcionamiento de la administración española en el periodo analizado mediante las comunicaciones existentes entre sus diferentes órganos, siguiendo la estructura de la división administrativa provincial pergeñada con el establecimiento del sistema político nacional liberal.

La mayor parte de la información ha sido obtenida del Archivo Histórico de la Real Academia de Bellas Artes de San Fernando (ARABASF), ubicado en Madrid, porque dicha academia fue la encargada de ejecutar la política de protección patrimonial en el país durante la segunda mitad del siglo XIX, de manera que su documentación se encuentra depositada actualmente allí, aun sin ser un organismo que pertenezca estrictamente a la Administración Central. Se ha acudido también al Archivo Histórico de la Biblioteca Nacional de España $(\mathrm{ABN})$ y al Archivo General de la Administración Central Española (AGA), ubicado este último en la ciudad de Alcalá de Henares.

El sistema bibliotecario nacional nació precisamente en este periodo, cuando el Estado, por la necesidad de conservar los bienes culturales y literarios de las comunidades religiosas suprimidas en los años 30 del siglo XIX, se ve forzado a desarrollar una política de protección y nacionalización de las colecciones bibliográficas de las órdenes del clero regular. Por lo tanto, interesa conocer cómo fue el proceso de creación del sistema de bibliotecas públicas provinciales, con qué fondos contaban, qué funciones desempeñaron y en qué medida podían responder a las necesidades de la sociedad de ese momento histórico, considerando los fondos existentes y los medios económicos disponibles para desarrollar una política bibliotecaria efectiva o, en su caso, identificar los problemas o deficiencias que se presentaron y que pudieron lastrar su efectivo desarrollo.

\section{LA ADMINISTRACIÓN HONORÍFICA COMO GESTORA DE LA POLÍTICA CULTURAL. \\ EL PROCESO DE RECOGIDA E INVENTARIACIÓN}

DE LAS BIBLIOTECAS DESAMORTIZADAS

Cuando mediante un real decreto de 25 de julio de 1835 (Gaceta de Madrid, núm. 211, 29 de julio de 1835) se suprimieron los monasterios y conventos que no contaban con más de 12 miembros se exceptuaron de los bienes destinados a la venta "[...] los archivos, bibliotecas, pinturas y demas enseres que puedan ser útiles á los institutos de ciencias y artes [...]”, aunque no fue hasta 
más adelante, por real decreto de 9 de marzo de 1836 (Gaceta de Madrid, núm. 444, 10 de marzo de 1836), que se propuso un fin para estos objetos, apareciendo por primera vez la mención a las bibliotecas provinciales.

Por real orden de 29 de julio de 1835 (ARABASF, leg. 55-2/2) se habían creado las comisiones civiles, que debían encargarse de realizar los inventarios de los bienes artísticos y literarios; una vez elaborados estos documentos, debían trasladar dichos bienes a la capital provincial y almacenarlos en un "parage cómodo y seguro", a la espera de su destino posterior. El problema fue que no se fijó un medio de financiación para el traslado de objetos y el pago de los comisionados, sino que se trató de que éstos trabajasen por "[...] patriotismo y puro amor á las artes".

Para tratar de mejorar esta situación se crearon mediante real decreto de 27 de mayo de 1837 (Gaceta de Madrid, núm. 907, 28 de mayo de 1837) las comisiones científicas y artísticas, fruto de las observaciones de diversos jefes políticos sobre "[...] los obstáculos que entorpecen el total cumplimiento [...]" de la anterior legislación. La mayor novedad que aportaban era la posibilidad de vender en subasta pública las obras que no se considerasen lo suficientemente valiosas para ser conservadas, con el fin de sufragar los gastos de elaboración de inventarios, traslado de los objetos y formación de las bibliotecas.

Sin embargo, las dificultades aún eran numerosas y, para tratar de agilizar la creación de estos centros, por real orden de 22 de septiembre de 1838 (Gaceta de Madrid, núm. 1407, 23 de septiembre de 1838) se permitió que las universidades asumieran en su provincia las funciones de las comisiones en la formación de bibliotecas, siguiendo el ejemplo valenciano (Muñoz Feliu, 2006). No obstante, a pesar de las medidas tomadas, los resultados de las comisiones científicas y artísticas fueron bastante similares a los conseguidos por las anteriores, según se reflejaba en las respuestas a la encuesta del 13 de julio de 1842 (Gaceta de Madrid, núm. 2834, 14 de julio de 1842; García López, 2003: 133-157).

Finalmente, se crearon mediante real decreto de 13 de junio de 1844 (Colección..., 1847: 292-298) las comisiones de monumentos históricos y artísticos, cuyo objetivo era tomar medidas "[...] que contengan la devastación y la pérdida de tan preciosos objetos [...] con el conocimiento, método y regularidad que son de desear". La novedad que introducían, en este caso, era la creación de una Comisión Central que debía ejercer como órgano centralizador pero que carecía de autoridad y poder ejecutivo sobre las provinciales.

Los primeros informes enviados desde las provincias eran alentadores: todas las comisiones parecían arrancar con energía y grandes propósitos, y sus miembros estaban, en general, en posesión de una formación amplia y 
en contacto con el mundo de las artes y las letras. A pesar de ello, estas comisiones, al igual que sus antecesoras, tampoco cumplieron por completo sus objetivos.

En este sentido, ha de tomarse en consideración que la actuación del gobierno a la hora de legislar y llevar a cabo la desamortización de los bienes culturales no fue un proceso planificado de antemano, sino que se fueron generando normas a medida que se presentaban las situaciones creadas tras la acción espontánea de las primeras exclaustraciones (García López, 2003). Por esta razón, y tal como indica Hernández Hernández (2002), la toma de posesión de los conventos y monasterios sin la suficiente planificación previa ni los medios para su correcta gestión acarreaba consecuencias negativas en lo concerniente al ámbito artístico. Deben tenerse en cuenta todos los problemas (extrínsecos e intrínsecos) a los que el Estado se enfrentaba, como la falta de colaboración de los religiosos, la improvisación en la supresión de los conventos, la guerra, la falta de motivación para conservar los bienes por parte de la administración, así como su descoordinación y la falta de recursos económicos, que sería una constante durante todo el proceso. ${ }^{1}$

Además del aspecto relativo a la organización del cuerpo encargado de la gestión cultural, para estudiar los fondos bibliográficos que formaron la base sobre la que se asentó el primer sistema bibliotecario nacional es preciso conocer antes ciertos aspectos del proceso de adquisición de éstos. Las bibliotecas públicas que se formaron durante la etapa liberal lo hicieron con los libros pertenecientes a las bibliotecas de las comunidades religiosas suprimidas. El primer paso era, por lo tanto, recoger esos libros de los edificios que anteriormente habían sido conventos y monasterios, para lo que era preciso realizar inventarios detallados del contenido de dichas bibliotecas así como de los demás objetos de carácter patrimonial y artístico que habían sido excluidos de la masa de bienes destinados a la venta.

Sin embargo, las disposiciones que se emitieron con el fin de llevar a cabo esta tarea fallaban por la base, pues no era posible conseguir una comisión adecuadamente formada por miembros competentes para la redacción de los índices y la valoración de las obras que debían conservarse y las que podían venderse, en cada convento y monasterio de cada localidad de cada provincia en todo el Estado, en el momento en que se efectuó la toma de posesión. Partiendo de esta falta de planificación, el resultado era previsible: los comisionados de Hacienda tenían como labor primordial recoger la documentación con valor legal para el cambio de propiedad de los bienes, así que se encargaron 
de las bibliotecas, al igual que de los demás objetos artísticos, de forma somera y superficial. ${ }^{2}$

Además, al transcurrir cierto tiempo desde la exclaustración hasta el traslado de los libros, no se podía recurrir a unas herramientas de descripción del fondo bibliográfico tan toscamente elaboradas para asegurar que éste se encontraba intacto, sobre todo cuando en ocasiones habían transcurrido más de diez años en los que los libros no habían estado custodiados ni protegidos adecuadamente. Este hecho tornaba bastante difícil averiguar si el fondo estaba completo y, más complicado aún, localizar las obras susceptibles de haber sido sustraídas.

Los elementos precisos para elaborar los inventarios eran los siguientes: personal cualificado, tiempo, un espacio de trabajo y recursos económicos; el problema residía en reunir todos los elementos a la vez. El personal cualificado pronto se cansó de trabajar sin remuneración, por lo que fue, poco a poco, abandonando sus actividades; el tiempo corría en contra de los libros, que cada vez estaban más deteriorados por las deficientes condiciones de almacenamiento; conseguir la cesión de un local que no necesitase obras u otro tipo de habilitación no era nada sencillo, y pagar un alquiler no era una opción al alcance de la mayoría de las comisiones. Probablemente, con recursos económicos suficientes se habrían podido subsanar los tres inconvenientes anteriores, pero éste fue el elemento cuya ausencia marcó más profundamente el desarrollo del proceso.

La venta de los objetos considerados como prescindibles en el lugar de origen para costear los gastos de formación de la biblioteca fue una buena idea, pero al ponerse en práctica produjo más problemas que beneficios: comenzaron a venderse las obras sin examinarlas correctamente, bien por desconocimiento, bien con la intención de deshacerse de un trabajo que no se quería realizar. Además, aunque se efectuase la venta y se obtuviese la cantidad de dinero necesaria para comenzar la formación de la biblioteca, no estaba garantizado que ese beneficio conseguido se fuese a utilizar con dicho

2 Éste era un punto sumamente importante en el proceso desamortizador, ya que estos documentos representaban el título de propiedad sobre los objetos y la conformidad de los antiguos poseedores (Burón Castro, 1995). Sin embargo, no se trabajó en este aspecto tanto como se precisaba, de modo que, cuando las comisiones científicas y artísticas se disponían a hacerse cargo de estos bienes, se encontraron con que los documentos que debían garantizar la entrega no existían (Bello, 1997). Entre las causas de esta negligencia se hallaban la falta de recursos económicos, el desinterés y la descoordinación de la administración. Según indica García López (2003, cap. 4), en algunas ocasiones sí se realizaron los inventarios de forma detallada, pero incluso en estos casos solía aparecer cierta cantidad de libros descrita genéricamente, aportando sólo su número o su peso, lo que Infantes (1997) denomina "biblioteca devaluada", generalmente volúmenes sueltos, desencuadernados o dañados. En los demás casos, los inventarios no se realizaron debido a la falta de personal para formar las comisiones civiles. 
fin, ya que en ocasiones los fondos se destinaron a otros asuntos mientras las comisiones (incluida la Central) reclamaban, sin resultado, el cumplimiento de la normativa. ${ }^{3}$ Con el objetivo de uniformar los trabajos de elaboración de los índices, la Comisión Central puso en circulación un modelo con los campos mínimos para identificar los fondos, que debían seguir las provinciales, e insistió en que habían de ceñirse a él. Pero éstas encontraron grandes dificultades para completarlo, ya que muchas comisiones indicaron que tardarían más tiempo en realizar el índice según el modelo de la Central.

No obstante, surgieron más problemas a la hora de recoger los fondos y llevarlos a las capitales de provincia, lugar en que debían establecerse las bibliotecas, pues se recogieron los libros de muchas de las órdenes suprimidas, trasladándolos para su posterior tratamiento, pero fueron muchos más los que no se recogieron: ${ }^{4}$ los que robaron los propios exclaustrados, los que fueron sustraídos por personas ajenas al proceso desamortizador, los hurtados por los responsables de dicho proceso, los que se vendieron cuando en realidad debían conservarse, ya fuese de forma legal o ilegalmente, por puro desconocimiento o con plena conciencia, y los que se destruyeron debido a las circunstancias de la guerra carlista, pero también a la inacción de las autoridades locales, a la dejadez de los responsables provinciales, a la impotencia de la administración honorífica, a la inercia de los órganos gubernamentales y a la ignorancia y la estrechez de miras de todos los participantes del proceso en general.

\section{El CONCEPTO DE BIBLIOTECA PÚBLICA EN LA SOCIEDAD DECIMONÓNICA}

Uno de los aspectos más importantes que se debe tener en cuenta al realizar un estudio sobre las bibliotecas públicas creadas durante el siglo XIX es que el concepto de biblioteca pública ha ido evolucionando con el paso del

3 En una comunicación al Ministro de Comercio, Instrucción y Obras Públicas el 20 de enero de 1848, la Comisión Central reclamaba el dinero procedente de la venta de objetos artísticos más de diez años atrás: "La Central no puede menos que aprovechar la presente ocasión para recordar á la ilustración de V.E., que en el año de 1837 ingresaron en las arcas del tesoro 460.000 r. procedentes de la enagenacion de seis cuadros originales de Zurbaran, que en la prov. de Cádiz fueron vendidos en la citada época (segun consta de documentos existentes en esta Sria.) y cuyo importe debió aplicarse como por Rl. órdenes estaba prevenido a la ereccion de Museos y Bibliotecas" (ARABASF, leg. 49-7/2).

4 García López (2002) estima esta pérdida en las tres cuartas partes del fondo bibliográfico perteneciente a las comunidades religiosas suprimidas. 
tiempo, de forma que la definición actual ${ }^{5}$ no es válida para abordar dicho estudio. Según indica García López (2007: 12) el concepto de biblioteca ha tenido diversos significados según el momento histórico:

Más que nada, de lo que se trataba era de romper la barrera normativa que podía imponer el que una biblioteca se considerase exclusiva de una comunidad y ante lo cual no se pudiese esgrimir ninguna "ley" o "derecho" que hacer valer para permitir el acceso a la misma. Es decir, que de iure la biblioteca fuese "pública", aunque de facto para un campesino iletrado fuese tan inaccesible la Real Biblioteca del siglo XVIII como cualquier biblioteca provincial del siglo XIX, fundamentalmente, porque la biblioteca no formaba parte del universo mental de esos grupos sociales. En este sentido, hablar de biblioteca pública era tanto como decir una biblioteca abierta a los eruditos o a los interesados en el estudio de las ciencias, lo que suponía sin duda una exigua minoría.

Un factor determinante para definir el público de las bibliotecas que se crearon en este periodo es el origen de sus fondos: salvo un porcentaje muy bajo de compras, donaciones o ingresos por depósito legal, los libros procedían de los conventos y monasterios suprimidos. Esto quiere decir que se trataba principalmente de obras de temática religiosa, muchas de ellas escritas en latín; éste era un fondo totalmente alejado del nivel cultural y del interés de la mayoría de la población española de mediados del siglo XIX. Se apunta aquí la falta de demanda social ante un fondo inadecuado como una de las principales razones de la deficiencia del sistema bibliotecario liberal. ${ }^{6}$

Además, la sociedad española no consideraba a la biblioteca pública como una institución proveedora del ocio o la instrucción obtenidos a través de la lectura, ya que ésta tenía lugar no solitariamente sino, por lo general, de forma colectiva en el hogar. Las lecturas eran compartidas por los distin-

5 Como, por ejemplo, la definición de IFLA/Unesco: "Una biblioteca pública es una organización establecida, respaldada y financiada por la comunidad, ya sea por conducto de una autoridad u órgano local, regional o nacional, o mediante cualquier otra forma de organización colectiva. Brinda acceso al conocimiento, la información y las obras de la imaginación gracias a toda una serie de recursos y servicios; está a disposición de todos los miembros de la comunidad por igual, sean cuales fueren su raza, nacionalidad, edad, sexo, religión, idioma, discapacidad, condición económica y laboral y nivel de instrucción” (IFLA, 2001: 8). Las funciones de ésta deben ser "[...] facilitar recursos informativos y prestar servicios mediante diversos medios con el fin de cubrir las necesidades de personas y grupos en materia de instrucción, información y perfeccionamiento personal comprendidas en actividades intelectuales de entretenimiento y ocio. Desempeñan un importante papel en el progreso y el mantenimiento de una sociedad democrática al ofrecer a cada persona acceso a toda una serie de conocimientos, ideas y opiniones" (IFLA, 2001: 8).

6 Baste como ejemplo el informe de Navarrete a la Comisión Central de fecha 26 de diciembre de 1845, en el que se indicaba acerca de Logroño que "[...] si se considera que sus vecinos, agricultores ó artesanos en su mayor parte, no pueden dedicarse á la lectura no faltara quien se oponga á que se inviertan cantidades que reclaman atenciones mas perentorias en un objeto que considera el pueblo como de lujo inútil [...]” (ARABASF, leg. 49-1/2) 
tos miembros de la familia, leídas en voz alta por uno de ellos a los demás. ${ }^{7}$ Los nuevos hábitos de lectura se fueron generalizando a lo largo del siglo a causa del aumento de los sectores de la población alfabetizada, para los que la lectura aún no era una actividad regular sino una "práctica excepcional", para la que recurrían a gabinetes de lectura, lectura pública y adquisición de libros de segunda mano (Romero Tobar, 1976); también son destacables las publicaciones por entregas periódicas, ${ }^{8}$ que servían para garantizar ingresos por parte de los editores y como una alternativa asequible para el público tanto en el ámbito económico como en lo relativo a la lectura (Botrel, 1996a).

La popularidad de las publicaciones periódicas no fue un fenómeno exclusivamente español, sino que fue la tónica general durante los años centrales del siglo XIX en todo el continente europeo; las publicaciones periódicas de carácter enciclopédico que incluían imágenes además de texto experimentaron un gran auge. En España surgieron títulos como El Laberinto, Periódico Universal, 1843; El Siglo Pintoresco, Periódico Universal, 1845; La Ilustración, Periódico Universal, 1849, o El Panorama Español, Crónica Contemporánea, editado entre 1842 y 1845, que recogía los acontecimientos políticos correspondientes a los años en que se desarrolló la guerra carlista. Aun cuando el costo de las técnicas para incluir las ilustraciones aumentaba el precio de estas publicaciones, esto no fue óbice para su difusión, si bien entre sectores de la población de carácter acomodado (Ferrer, 2012).

Estas imágenes, además de tener utilidad como una marca visual para la lectura y servir como un acicate para fomentar la adquisición de estas publi-

7 "Aún hoy, muchas personas se enteran de las noticias oyéndolas leer a un locutor de televisión. La televisión es quizá una ruptura con el pasado menor de lo que generalmente se supone. En cualquier caso, para la mayoría de las personas a lo largo de la mayor parte de la historia, los libros han tenido más oyentes que lectores. Más que verse, se oían” (Darnton, 1994: 191). A este respecto, al abordar la oralidad de la lectura no debe perderse de vista el importante papel del ciego, estudiado por Botrel (1993). Para reforzar el cambio en la consideración del aspecto de la lectura correspondiente a su práctica oral, puede observarse la anécdota recogida y analizada por Martínez Martín (2003), en la que explica cómo, con objetivos políticos, se criticó fuertemente la conducta de la condesa de Espoz y Mina, aya de las infantas Isabel y Luisa Fernanda, a las que leía en voz alta durante sus paseos en carruaje. En dichas críticas se afirmaba que la primera leía para sí misma y se consideraba este acto irreverente y ofensivo. Este hecho se desmintió en la Gaceta mediante un comunicado oficial en el que se explicaba que ésta leía en voz alta a petición expresa de las infantas y como parte del programa educativo de las mismas. Se revela en este incidente, según indica el autor, cómo la práctica de la lectura íntima, sobre todo ejercida por mujeres, "[...] era entendida por la Iglesia como un fermento de pasiones y por tanto de naturaleza peligrosa. El colectivo de mujeres letradas, como una de las nuevas categorías de lectores, fue el público más proclive a la literatura, sobre todo novelada, que leía en silencio y a solas, en el retiro, que contrastaba con un tipo de lectura colectiva de naturaleza sacra vinculada al ejercicio devoto y a la práctica de la liturgia religiosa [... L La lectura en voz alta y compartida era la lógica natural de la relación con lo escrito. Y tenía un carácter sacro. También de entretenimiento y de hecho, era la forma de enseñanza de la lectura por definición” (Martínez Martín, 2003: 141).

8 Para ampliar esta información, consúltese Baulo (2003). Además, una vez finalizadas solían reunirse en un solo volumen para su venta. Véase para el estudio de una de ellas el trabajo de Carrillo (1974). 
caciones como objeto de posesión, "[...] pueden ser la representación visual y fácil de algo que a pesar de la profusión de detalles y de su incesante dramatismo permanece abstracto" (Botrel, 1996a: 56). ${ }^{9}$

Otra de las claves para formarse una idea del concepto de biblioteca pública imperante aparece recogida en la real orden de 28 de agosto de 1843 (Gaceta de Madrid, núm. 3303, 5 de octubre de 1843), que fijaba los horarios de asistencia a la Biblioteca Nacional y a la de los Estudios de San Isidro. En este texto se indica que las bibliotecas eran "[...] un sitio de estudio y de consulta, y de ningún modo un gabinete de lectura para recreo y pasatiempo [...]", a lo que se añadía la prohibición expresa del préstamo de libros. En la misma línea se encontraba Eugenio de Tapia, bibliotecario de la Nacional, que exponía su malestar ante ciertos usos de la biblioteca (ABN, 0106/03). Éste consideraba que debía alejar del centro a los lectores de novelas, que solían ser jóvenes, cuyas lecturas el bibliotecario tildaba de frívolas y poco recomendables desde el punto de vista moral. ${ }^{10}$

En definitiva, el concepto de biblioteca pública era muy diferente del actual; además, al valorar las bibliotecas creadas durante la década moderada deben tenerse en cuenta los problemas y carencias a los que se enfrentaban y que debían subsanar, que fueron factores determinantes en la organización de los fondos y servicios de las mismas.

\section{FUnCIONES ATRIBUIDAS A LAS BIBLIOTECAS PÚBLICAS}

Otro de los aspectos a estudiar en este trabajo es determinar cuáles fueron las funciones de las bibliotecas públicas en relación con la tipología de los fondos disponibles. Se han analizado los documentos de la época y conforme a ellos se establecieron las principales funciones de las bibliotecas públicas, que responden tanto al discurso que mantenían los gestores encargados de la política cultural y bibliotecaria y las intenciones que manifestaban como a la política que se llevó a cabo de forma efectiva. Además, no debe perderse de vista la diferencia existente entre la noción que se tenía a mediados del siglo XIX acerca de estos centros y la que existe hoy día. Hay que tener en cuenta el cambio producido en la mentalidad del público potencial de las bibliotecas acerca de la utilidad de éstas y del impacto que tenían en sus vidas, tal como ya se ha indicado previamente. De esta forma, se han identificado cuatro funciones principales de las bibliotecas públicas, atendiendo al estudio de la

9 Para profundizar en la relación entre el texto y la imagen en la prensa del siglo XIX, consúltese Fontbona (2003).

10 Para profundizar en la crítica y censura moralista de la novela, consúltese Lopez (1998). 
bibliografía especializada y al análisis de los diferentes casos que se dieron en las provincias españolas:

- Depósitos del patrimonio cultural.

- Control social.

- Instrucción pública y formación profesional.

- Servicio a la comunidad de docentes y estudiantes.

Las bibliotecas públicas se concebían y se constituyeron como depósitos del patrimonio cultural del país, con fines puramente conservacionistas, debido a la gran cantidad de obras antiguas que albergaban, sin utilidad para los usuarios potenciales pero con gran valor artístico e histórico, y a la importancia que fue tomando el depósito legal. En cuanto a la evolución europea, Fernández Abad (2006: 102) indica que, ya que los centros contaban con fondos antiguos, se centraban en su conservación y organización, dando como resultado "bibliotecas-museo". Fernández Prado (1991) sostiene, corroborando esta afirmación, que en la creación de bibliotecas y museos primaba el objetivo de conservar el patrimonio sobre la educación popular.

Abundan los ejemplos en los que las diferentes comisiones, comenzando por la Central, explicaban la importancia de la función de las bibliotecas públicas como depósitos del patrimonio cultural, recogiendo éste, organizándolo y cuidando de su preservación para fines históricos, arqueológicos o paleográficos. Por ejemplo, en el informe acerca del pobre desempeño de la Comisión Provincial de Almería se indicaba con mucha claridad que el objetivo principal de la administración honorífica con la creación de las bibliotecas públicas debía ser no solamente la conservación de las bibliotecas sino también de los edificios. ${ }^{11}$

Una visión similar compartía la Comisión Provincial de Oviedo, que propuso reunir con la mayor celeridad posible la información precisa sobre los edificios notables que debieran conservarse, cuidando especialmente los de arquitectura típica asturiana, "[...] y asimismo dar los pasos conducentes á la adquisicion de los manuscritos interesantes para la historia ó de merito

11 "El pensamiento que ha presidido á la creacion de las comisiones de monumentos y á la consiguiente formacion de museos y bibliotecas provinciales. Este pensamiento no ha sido tanto el deseo de reunir y conservar lo existente, como preparar en cada provincia un centro de su riqueza artistica y literaria conocidas y por conocer, en el cual refluyan las nuevas adquisiciones, que el celo de las comisiones, vaya haciendo en proporcion á sus recursos. Agreguese a esta consideracion la de que a veces los museos y bibliotecas son un medio de conservar los edificios en que se coloquen, librandolos de este modo de la ruina que las amenaza. La central guiada siempre por esta mira ha aconsejado que se destinen para museos y bibliotecas los edificios mas notables de cada provincia”. Informe evacuado con fecha 16 de junio de 1847 por la Comisión Central al Ministro de Comercio (ARABASF, leg. 44-1/2). 
paleográfico, de que debe posesionarse, en cuya importante tarea ha hecho algunos adelantos hasta el dia" (ARABASF, leg. 50-1/2, Personal-Organización...). De esta forma, la Comisión provincial dejaba claro que su visión respecto a las bibliotecas no se basaba en los servicios al público, sino en la conservación de documentos considerados valiosos.

El Jefe Político de Baleares, en el discurso de apertura de la Biblioteca Provincial, comparaba éstas con "[...] una especie de templos [...]" destinados a custodiar el conocimiento humano con el fin de ofrecérselo a los hombres sabios, para que éstos, uniendo esos conocimientos al suyo propio, pudieran ilustrar al resto. Denominaba a las bibliotecas como monumentos del saber y depósitos de la ilustración (ARABASF, sig. F7881). La misma idea, aunque con un poso nacionalista, se observa en la provincia de Burgos, en la que se indicaba que los restos que se habían conseguido conservar de los bienes expropiados darían una idea al público de "[...] las glorias y los gratos recuerdos de Castilla" (ARABASF, leg. 46-7/2).

Existía una marcada tendencia por parte de las élites ilustradas a considerar las bibliotecas públicas como una alternativa "sana" y "decorosa" frente a otras opciones para invertir el tiempo que dedicaban al ocio las clases bajas, por ejemplo, según citaban frecuentemente, las tabernas. Esta visión paternalista trataba de utilizar la biblioteca pública como una herramienta de control social, visión compartida por Eugenio de Tapia (ABN, 0106/03), que al solicitar un nuevo edificio para la Biblioteca Nacional añadía que, aprovechando el traslado, se presentaba la oportunidad de "[...] disminuir la molestisima tarea que en el dia ocasionan á los empleados del establecimiento los muchos lectores de novelas, jóvenes de pocos años por lo comun, y cuya exigencia suele ir acompañada de poca urbanidad". La propuesta de Tapia era conservar únicamente las obras de mayor "merito y reputacion" y esconder el resto en un cuarto aparte debido a que eran "[...] frivolas, y muchas poco recomendables por la moralidad". ${ }^{2}$

También en la provincia de Valladolid (ARABASF, leg. 54-7/2), al explicar el origen de la Biblioteca del Colegio de Santa Cruz, el Jefe Político indicaba que había sido fundada por el cardenal Pedro González de Mendoza en 1492, cuyas motivaciones habían sido, según las constituciones que había elaborado para el gobierno, tanto de este centro como del propio Colegio,

12 Las bibliotecas de préstamo que comenzaron a formarse en Europa a partir de 1750 recibieron críticas semejantes a las emitidas por Eugenio de Tapia. Estas bibliotecas eran utilizadas por estudiantes, aprendices de artesanos, mujeres, integrantes marginales del mundo académico (como preceptores), militares o secretarios. Sus lecturas comprendían "[...] historias de caballeros, bandoleros y fantasmas, las novelas sentimentales y sensibleras y sagas familiares [...]", y eran tachadas de "«expendedores de veneno moral y burdeles» que servían su «arsénico del espíritu» a jóvenes y viejos, ricos y pobres” (Wittmann, 2011:379-380). 
"[...] el darle gran pena considerar que muchos dejaban de darse á la virtud y letras por no tener con que sustentarse, otra el bien público universal de España, y el favor de las letras y buenas artes [...]" además, también le había motivado "[...] la honra y autoridad de Valladolid y de su Universidad".

La naciente burguesía trataba de asentar su hegemonía, entre otros medios, mediante el control cultural, al igual que había hecho la nobleza en épocas anteriores, tal como explica San Segundo Manuel (1996), asentando su ideología a través de las universidades medievales. Fernández Prado (1991: 82) explica cómo el Estado, al aumentar su intervención en el arte y la cultura, si bien de forma tradicionalista y conservadora, "Se convierte en el protector de unas formas culturales vinculadas al predominio social de la aristocracia y adaptadas a la nueva estructura del consumo burgués". De esta forma, las bibliotecas, más que una necesidad social a cubrir, eran una oportunidad de control social. ${ }^{13}$

Muy cercana a la función de controlar el ocio de los grupos populares mediante el uso de la biblioteca pública se encontraba la función de instrucción pública y formación profesional, siguiente paso en el uso útil para la sociedad de esta institución: tras evitar lo que se denominaba "ocio pernicioso" mediante la cultura, la evolución natural era aprovechar el tiempo invertido en este centro para la mejora de su formación profesional, creando una mano de obra más preparada y cualificada, que resultaba necesaria para la nueva sociedad industrial que se estaba abriendo paso. ${ }^{14}$ Según indican Trías

13 Coincide con esta visión Viñao Frago (1991: 312), quien indica que en la época de transición entre el absolutismo y el liberalismo burgués, la política educativa tenía como objetivo "[...] formar vasallos o súbditos -que no ciudadanos- fieles y laboriosos, amantes del rey y de la nación, disciplinados, útiles y productivos, sin poner en cuestión el orden estamental y las jerarquías establecidas y asegurando, a la vez, la preeminencia de esas nuevas clases acomodadas legitimadas por el saber o servicios prestados a la nación, al rey y al Estado, es decir, por la creación de cultura, poder y riqueza”. Puelles Benítez (1999), al analizar la nueva educación producto del triunfo político del moderantismo, indica el cambio que debía realizarse en la idea de educación universal y gratuita: se había pasado de tratar de alcanzar la igualdad de la ilustración a conseguir la primacía de la propiedad, que traía consigo la desigualdad ya desde la educación, que no era la misma para todos. Así, la educación pasaría, de una herramienta democratizadora o revolucionaria, a un instrumento de poder.

14 "El mercado comarcal se basaba en una agricultura de subsistencia con fuerte proporción de autoconsumo, que intercambiaba sus escasos excedentes (una vez deducidas las partes que correspondían al señor y la Iglesia) por los productos de una pequeña industria artesana local, ejercida por hombres que seguían siendo, con frecuencia, medio campesinos. En el interior del mercado nacional, en cambio, la división social del trabajo se ha intensificado: las distintas ramas de la producción se han separado definitivamente de la agricultura y ésta ha tomado, a su vez, un carácter nuevo, en el sentido de que tiende a producir mercancías para intercambiarlas por productos industriales" (Fontana, 1973: 15). Además, al perder el mercado colonial y tener que depender exclusivamente del español, la burguesía industrial se percató de que había muchas posibilidades para desarrollar éste, ya que se encontraba postrado por la explotación de la oligarquía feudal: "Las ideas de los libros prohibidos dejaban de ser principios generales y se convertían en instrumentos para la comprensión del mundo en que vivían. El despotismo había perdido su barniz de ilustración y se había convertido en freno que obstaculizaba el progreso. Así se comprenderá que, rompiendo una larga tradición de colaboración con la monarquía, los burgueses catalanes participen ahora en tentativas insurreccionales para derribar el absolutismo y restablecer la constitución” (Fontana, 1973: 15). 
y Elorza (1975) para el caso catalán, la clave estaba en el control moral y en la formación profesional.

No obstante, la burguesía trataba de encontrar el delicado equilibrio educativo que les permitiera alcanzar sus objetivos. En este sentido, Ponce (1987) llama la atención sobre el doble filo de la creciente actividad educativa emprendida por la nueva clase emergente: se precisaba aumentar la instrucción de las masas con el fin de que éstas adquiriesen las habilidades necesarias para la producción industrial, pero se temía que esta instrucción sirviese también como herramienta emancipadora.

El papel del libro en este proceso de formación se vio reforzado por el cambio en el campo editorial, que pasó de concebir el libro como un "[...] objeto suntuario y de nuevo deleite [...]”(Fernández, 2003: 672) a tomarlo como una herramienta de consulta permanente que reforzaba la formación continua en el nuevo contexto industrial, en el que los avances en estos campos aportados por los libros pasaban a ser "[...] necesarios en el engranaje de una nueva sociedad cambiante y asombrada por las novedades del progreso en todos los órdenes" (Fernández, 2003: 672).

Entre los defensores de la biblioteca pública como entidad formativa frente a la biblioteca-museo se encontraba el director del Instituto de Enseñanza Secundaria de Orense, que esgrimía sus argumentos a favor del uso de la biblioteca del centro para la formación y la instrucción públicas (AGA, Educación y Cultura, caja núm. 6.738, carpeta núm. 6.584-80). ${ }^{15}$ En el caso de Navarra (ARABASF, leg. 50-4/2), tras examinar las obras de que disponía la Comisión Provincial para formar la biblioteca, se había llegado a la conclusión de que no eran aptas para el servicio al público dado que se trataba de obras de carácter religioso y, según indicaba dicha comisión, eran muy pocas las que podían ser utilizadas para servir a la ilustración pública en los campos de las artes y las ciencias, objetivo que consideraba principal de las bibliotecas en ese momento.

Finalmente, hay que contemplar el uso de las bibliotecas públicas por parte de la comunidad de docentes y estudiantes. Por un lado, eran los que tenían más fácil el acceso intelectual al contenido de dichos centros; por otro, la mayoría de las bibliotecas acabó, a pesar de ser provinciales y públicas, situada en una universidad o un instituto de enseñanza secundaria, con

15 "Poco importa que las Comisiones de monumentos tengan interes en conservar los libros como meros objetos arqueológicos; por que es lo cierto que los libros, por su especialidad tienen otro carácter que el de su mayor ó menor rareza y antigüedad, cual es el de servir y gastarse en el uso continuo de los que desean ó necesitan consultarlos; y por consiguiente desde el momento en que reunidos constituyen una biblioteca mas ó menos crecida, cambian de objeto los libros, y salen de dominio particular de la arqueología para pasar al de humildes servidores de quienes puedan necesitarlos". 
lo que el acceso físico también beneficiaba a este colectivo. ${ }^{16}$ En primer lugar hay que considerar el impulso que los políticos liberales dieron a la enseñanza en general; según Ruiz Berrio (1970: 13-14), la educación fue considerada tanto por los políticos, los economistas, los intelectuales y las autoridades religiosas como la solución a todos los males de comienzos del siglo XIX. ${ }^{17}$

Viñao Frago (1991) señala cómo la escolarización había aumentado muy levemente desde 1797, en que la asistencia a las aulas entre los seis y los 13 años era del $23 \%$ hasta 1831, en que estaba situada en el $24 \%$. Hernández Díaz (1986) destaca el periodo 1840-1860, cuando el aumento de la escolarización primaria elevó, a su vez, la tasa de población alfabetizada, ya que el número de escuelas primarias pasó de 12719 en 1830 a 20743 en 1855 , y el número de personas con conocimientos de lectura y escritura pasó de 1290257 en 1841 a 3129921 en 1860, según los datos aportados.

No obstante, este autor no pierde de vista la vertiente proselitista que ofrecía el control de la educación, ${ }^{18}$ aunque, tal como explica, no se consiguieron totalmente los objetivos políticos en este punto: a pesar de que los logros eran abundantes debido a que se comenzó a trabajar partiendo desde una situación muy elemental, no se alcanzó el objetivo político previsto, que trataba de primar los intereses burgueses creando "[...] una educación y una escuela para todos, pero no todos al mismo tiempo ni todos de la misma forma y grado” (Hernández Díaz, 1986: 79). Se consideró que para alcanzar

16 No obstante, el hecho de que la biblioteca se encontrase en el seno de una institución de carácter educativo no garantizaba la facilidad en el acceso a sus fondos a la comunidad de estudiantes, como ocurrió en el caso valenciano, según indica Paz (1913: 364): "La Biblioteca de la Universidad se abría en 1840 , de nueve á doce y de tres á cinco ó de cuatro á seis, según la estación; permanecía cerrada por la tarde, durante todo el mes de Julio, más los días de lluvia, para impedir que en ellos acudiesen, más o menos tumultuosamente, á la sala los estudiantes que no podían aguardar en los patios la apertura de las clases. La Biblioteca, con estas restricciones y con las que, en general, se adoptaban contra los estudiantes, era poco frecuentada. Rara vez se reunían más de 10 ó 12 lectores, con lo cual no se cumplían del todo los deseos del fundador hacia la juventud que asistía á las clases".

17 Gil de Zárate (1995, t. I: V-VI ) afirmaba que "Para las gentes que saben apreciar sus beneficios [de la instrucción pública], es sin duda el primero de todos, por la inmensa influencia que ejerce, no solamente en los destinos individuales del hombre, sino todavía más en la suerte general de los Estados. Sin buena enseñanza el comercio decae, las artes no existen, la agricultura es mera rutina, y nada prospera de cuanto contribuye al bienestar de la patria. En vano se forman proyectos, se promueven empresas; se habla de obras públicas, de ejércitos, de escuadras; nada se hace que no sea raquítico, miserable; o los recursos, asi del gobierno como de los particulares, se agotan en esfuerzos estériles que solo patentizan la impotencia de una sociedad cuyos miembros se hallan paralizados por la ignorancia [...] En otras épocas habrá podido la barbarie triunfar de la civilización: hoy la victoria obedece á la ciencia, y los pueblos más ilustrados son tambien los más poderosos".

18 "Convendría recordar, sin embargo, que una de las funciones prioritarias de la escuela en la estructura social de la España del siglo XIX es la inculcación en el ciudadano de valores y modelos de conducta disciplinados y autoritarios, la reproducción del sistema social imperante" Hernández Díaz (1986: 75); Peset y Peset (1974: 436) coinciden afirmando sobre el Plan Pidal de 1845 que Gil de Zárate diseñó un sistema bien articulado que favorecía el control del sistema educativo por parte de "[...] la clase social que había encumbrado a los moderados". 
el control de la educación, al igual que en el resto de los ámbitos, ésta debía estar fuertemente centralizada y controlada férreamente desde el Gobierno, tal como indica Carr (1982).

Según explica Ponce (1987), la denominada reforma educativa liberal sería en realidad una revolución en la educación. La diferencia entre reformas y revoluciones reside en que las primeras tienen lugar tras cambios sociales no traumáticos, es decir, diferencias entre las clases sin que haya una ruptura entre ellas; las reformas son, pues, un "[...] contragolpe en la educación de un proceso económico mediante el cual una sociedad aristocrática y agrícola retrocedía sin claudicar frente a una sociedad comerciante e industrial" (Ponce, 1987: 165-166). No obstante, el mismo autor señala dos revoluciones acaecidas en la historia de la educación: la división en clases de la sociedad primitiva y la sustitución del feudalismo por la burguesía.

En cuanto al papel de las bibliotecas en la educación, Cruz Solís (2008) indica que éstas fueron citadas por primera vez como un recurso pedagógico en 1845 , cuando Gil de Zárate señaló que consideraba indispensable que todos los institutos de enseñanza secundaria tuvieran su propia biblioteca, de importancia similar a los laboratorios de ciencias y los gabinetes, aunque los problemas económicos no permitieron desarrollar esta idea. La influencia del sistema educativo sobre las bibliotecas es determinante cuando éstas son concebidas como parte de ese sistema de educación y formación, tal como indica San Segundo Manuel (1996), aunque hay que tomar en consideración el resto de funciones encomendadas a las bibliotecas que fueron creadas a mediados del siglo XIX en su conjunto para poder comprender la esencia de las mismas. ${ }^{19}$

En Zaragoza, a pesar de que la biblioteca de la universidad debía ser pública, ya que acogía libros procedentes de órdenes suprimidas, desde el prin-

19 "Las reformas que se llevaron a cabo, en este sentido, no fueron provocadas por la presión de la base social o iniciativa popular sino por una minoría culta, liberal que detentaba el poder y pretendía desarrollar la educación. Estas políticas liberales gestaron la creación de bibliotecas públicas [...] Los diversos modelos educativos han instado a la creación de distintos tipos de bibliotecas. En el siglo XIX el modelo de educación liberal propició la creación de bibliotecas públicas populares [la autora se refiere a las creadas a partir de 1868], mientras que con anterioridad había regido el modelo escolástico que fue creador de las bibliotecas universitarias restringidas a la burguesía y al clero. De esta forma, las ideas ilustradas pretendieron la implantación de un nuevo sistema de enseñanza, y tuvieron la apoyatura del nuevo estado liberal nacido conforme al modelo francés tras la Revolución Francesa. Así se integró un sistema educativo diametralmente opuesto al escolástico. Este sistema educativo se situó al servicio de un capitalismo de tipo liberal conformado por intelectuales y por las nuevas clases cultivadas, lo que incidirá, por tanto, en la política bibliotecaria. A partir de estos planteamientos, cabe señalar que las iniciativas de creación de bibliotecas, de carácter público en el siglo XIX, se produjeron con el fin de desarrollar la educación, insertas en las políticas educativas que pretendían erradicar el analfabetismo, que en el siglo XIX abarcaba a un 80 por 100 de la población, más que el de difundir la cultura y la lectura” (San Segundo Manuel, 1996: 228). 
cipio del curso había estado disponible solamente para los catedráticos y los alumnos, aunque se había dispuesto que atendiese al público en general cuando se presentase al trabajo el bibliotecario segundo (AGA, Educación y Cultura, caja núm. 6.735, carpeta núm. 6.581-2). En el caso de Salamanca, el rector trataba de fomentar el uso por parte de los alumnos de las obras procedentes de exconventos y exmonasterios, que la universidad aún tenía depositadas en otro edificio. ${ }^{20}$

La misma opinión se extrae de las declaraciones de la Comisión Provincial de Badajoz (ARABASF, leg. 44-5/2), que afirmaba que tanto la biblioteca como el museo que debían formarse eran de vital importancia ya que nunca habían existido instituciones de ese tipo en la provincia, a pesar de haber una gran necesidad de ellas para fomentar la literatura y las artes, ya que no solamente en esta demarcación, sino en todo el país se había prestado una atención deficitaria a la educación pública. No obstante, al informar acerca del estado de los libros, se decía que se trataba de obras incompletas y de una temática inadecuada para contribuir a la ilustración, añadiendo que los niños no abrirían "ni por curiosidad" unos libros tan viejos y estropeados.

Según se ha podido observar, el criterio para fijar los objetivos variaba de unas provincias a otras en función de la opinión de los responsables de las comisiones provinciales o de sus comisionados, ya que no se fijaron en la normativa directrices a este respecto ni la Comisión Central fue clara al determinar la finalidad de los centros que debían crearse. De este modo, al igual que en otros aspectos del proceso, las funciones de las bibliotecas públicas fueron determinadas por cada provincia en el desarrollo de sus actividades, por lo que no estaban planificadas de antemano, sino que surgieron a lo largo de este periodo, adaptándose a las nuevas situaciones que se iban generando.

Las disposiciones del gobierno fueron, por lo tanto, muy vagas en cuanto a la función que debían tener las bibliotecas públicas: en la normativa y las disposiciones emitidas se hablaba de crear "centros de la riqueza literaria y artística provincial" o de "conservar el patrimonio de forma que redundara en el beneficio público". Estas expresiones eran tan poco explícitas y de significación tan amplia que finalmente corrió a cargo de la administración provincial determinar dichas funciones. Por lo tanto, debido a la ambigüedad de las directrices estatales se dejó al arbitrio de las comisiones provinciales un aspecto fundamental para el afán centralizador gubernamental, de modo

20 "Contiguas al gran salón de la Biblioteca hay localidades muy a proposito para su colocación, que se obtendria a poca costa aprovechando al efecto la estanteria en que hoy se hallan; una vez colocados, una sola mirada despertará la curiosidad de la juventud que acude presurosa a este antiguo Centro Universitario ávida de saber y de ciencia y podría satisfacerse mas cumplidamente su noble deseo de ilustracion" (AGA, Educación y Cultura, caja núm. 6.739, carpeta núm. 6.585-37). 
que lo que se consiguió fue una gran disparidad de modelos en lugar de la uniformidad deseada inicialmente.

\section{CARACTERÍSTICAS Y UTILIDAD DEL FONDO BIBLIOGRÁFICO NACIONALIZADO}

En cuanto a la aplicación bibliotecaria de los libros procedentes de las órdenes suprimidas, había varias posibilidades para emplear este fondo bibliográfico recién adquirido: podía formarse una biblioteca provincial íntegramente a partir de ellos, o podían pasar a formar parte del fondo de otra biblioteca, que podía pertenecer a un centro de enseñanza (universidades o institutos de educación secundaria), a una sociedad o academia o, finalmente, a una biblioteca arzobispal, episcopal, de un seminario o de otra institución de carácter religioso. Esta última era la opción más lógica atendiendo a la naturaleza de los libros, como se explicará más adelante.

Las obras expropiadas eran en su mayoría de temática religiosa, aunque también era frecuente encontrar libros sobre materias como filosofía, derecho o historia. Sin embargo, eran muy escasos los ejemplos de otro tipo de fondos, como en las provincias de Oviedo, Segovia y Soria (ARABASF, leg. 50-1/2, leg. 52-4/2, y leg. 53-4/2), en que se encontraban materias como literatura, geografía y ciencias exactas y aplicadas (en los casos de Oviedo y Segovia, de los que consta la compra de libros, es muy posible que los de estas materias fueran producto de las adquisiciones efectuadas por el centro y no de la herencia de la desamortización); además, la mayor parte estaban escritos en latín. Las obras, por lo general, estaban totalmente desactualizadas, ya que se trataba en su mayoría de ediciones antiguas y desfasadas de los siglos XVI, XVII y XVIII; de hecho, en muy pocos casos se contaba con obras del siglo XIX. Como agravante, había más volúmenes dañados o incompletos que íntegros.

La utilidad del fondo procedente de los exconventos y exmonasterios era, por lo tanto y como poco, cuestionable. Si se añade la consideración de los gastos que generaban su conservación y tratamiento, que en la mayoría de los casos no se podían cubrir, estos libros eran más un estorbo que una ventaja, por lo que en ocasiones se consideró que el destino idóneo para ellos era su incorporación a la biblioteca de un centro religioso, tal y como ocurrió en el caso balear, en Santander o en Toledo (ARABASF, leg. 45-1/2, leg. 7-5/2 y leg. 53-1/2).

En cuanto a la cantidad de volúmenes que pasaron a formar parte del patrimonio bibliográfico nacional procedentes de órdenes suprimidas, deben tenerse en cuenta ciertos aspectos por los que no se asignó la totalidad del fondo religioso a las nuevas bibliotecas provinciales, dependientes del Estado: 
- La falta de exhaustividad en la recolección, pues no todos los libros fueron recogidos a la vez, sino que se trasladaron a la capital poco a poco; en muchas ocasiones no se llegaron a reunir todos, sino que quedaron depositados en los edificios de los exconventos y exmonasterios durante años e incluso, en ocasiones, no se recogieron los libros hasta después de la venta de los inmuebles.

- El número del cálculo aproximado de volúmenes que existían en un depósito y el número real que se constataba tras su examen podía variar ampliamente tanto a la baja como al alza. Esta variabilidad era más acusada cuanto mayor era el tiempo transcurrido entre el almacenamiento de los libros y el examen; además, en muchos casos había varios depósitos dependientes de diferentes órganos o autoridades y cuya existencia no constaba a todos los implicados en su gestión.

- Están excluidos de este cómputo los libros que fueron robados, ocultados y nunca encontrados, vendidos irregularmente o destruidos antes de realizar los inventarios, que fueron la mayoría.

A los libros procedentes de la desamortización se añadían los obtenidos mediante otros medios de adquisición, aunque éstos fueron, en comparación con el primer método, mínimos. Las donaciones eran un sistema de incremento del fondo bibliográfico común, sobre todo en las bibliotecas que dependían de centros de enseñanza. ${ }^{21}$ En los demás casos apenas tenían incidencia ni relevancia, debido al escaso volumen de estas aportaciones y la poca pertinencia de las obras para un centro público. Muy similar era el supuesto del depósito legal: las obras obtenidas mediante este sistema poco tenían de interesante para una biblioteca pública, y apenas merecían el trabajo y esfuerzo que requería conseguir el cumplimiento de la normativa, ya que por lo general se encontraban muchas dificultades en la recolección de estos libros. ${ }^{22}$

Por último, las compras eran el mejor método de adquisición, ya que las obras se ajustaban exactamente a las necesidades de la biblioteca; el problema residía en la endémica escasez de fondos que impedía que se destinasen recursos económicos a este fin. Únicamente disponían de dinero para compras las bibliotecas de universidades y honrosas aunque escasas excepciones, como las provincias de Guadalajara, León (ARABASF, leg. 48-3/2 y leg. 48-

21 Pueden citarse como ejemplo las provincias de Zaragoza o Teruel (ARABASF, leg. 54-4/2, y AGA, Educación y Cultura, caja núm. 6.739, carpeta núm. 6.585-4).

22 En el caso de Valencia existieron grandes dificultades para la recolección de los libros, por lo que la Biblioteca Nacional tuvo que recurrir a la mediación del Ministerio de Gobernación, ya que la Secretaría del Gobierno Civil no entregaba las obras. En cuanto a la utilidad de los libros, tanto el comisionado de Granada como el de Orense dejaron constancia de la poca pertinencia de éstos (ABN, 0448/8). 
8/2, Museo...) o Segovia (AGA, Educación y Cultura, caja núm. 6.735, carpeta núm. 6.581-2; ARABASF, leg. 52-4/2). No obstante, la dotación de 2000 reales de vellón, partida anual para gabinetes y bibliotecas de los institutos de enseñanza secundaria, redundó en mayor o menor medida en beneficio de las bibliotecas provinciales acogidas en estos centros.

En cuanto al proceso inverso, la venta de obras de las bibliotecas públicas para conseguir recursos económicos, a pesar de plantearse como una alternativa viable a la financiación directa estatal, generó más problemas que soluciones. En la mayoría de las provincias se realizaron enajenaciones de forma irregular, hasta que el gobierno emitió la normativa con las directrices inspiradas por la petición de la Comisión Provincial de Cáceres. ${ }^{23}$ El problema residía en que las provincias consideraban inútiles los libros antiguos y de temática religiosa para una biblioteca pública; y su tratamiento y conservación un despilfarro de los escasos fondos con que contaban, por lo que querían venderlos y adquirir obras más modernas y pertinentes. ${ }^{24}$

La Central, por el contrario, cada vez fijaba normas de conservación más estrictas y vigilaba más estrechamente su cumplimiento, despertando las críticas de las provinciales. Estas críticas tenían su justificación en el hecho de que las comisiones se veían obligadas a enfrentarse a unos gastos que no podían cubrir generados por unos libros a los que no veían ninguna utilidad. Hasta que el gobierno no facilitara los fondos necesarios para su conservación, los exiguos beneficios obtenidos de la venta del material considerado prescindible no iban a solventar el problema de la gestión de las bibliotecas.

23 No se debían enajenar libros de materias predicables a no ser que estuvieran triplicados; sólo se podían vender duplicados de una misma edición en el caso de las biblias, obras históricas, literatura y antigüedades; los tomos sueltos de estas materias debían conservarse ante la posibilidad de completar una obra entre varias provincias. Las razones que se aducían para la conservación de estas obras eran: "[...] ya para la ilustración de la historia de la literatura y tipografia, ya para consultarlos como estudios filológicos, ya en fin como fuentes de la historia politica de las épocas á que cada uno de aquellos libros pertenecen". Finalmente se emitió una real orden de 1 de octubre de 1847, del Ministerio de Comercio, Instrucción y Obras Públicas, que determinaba que "[...] se autorice tanto á la com. de Cáceres, como á todas las demas del Reino para que puedan enagenar todos los duplicados de la una misma edicion de las obras que ecsistan en sus Bibliotecas, dando en cada caso cuenta circunstanciada; y que para enagenar cualquiera otra obra ó volumen, deban pedir y obtener una autorizacion especial" (ARABASF, leg. 46-5/2).

24 En este sentido se expresaban algunos responsables de la gestión provincial de los bienes procedentes de las órdenes suprimidas, como por ejemplo, Juan Guerra, jefe político de Cáceres, que con fecha 27 de agosto de 1846 se dirigía a la Comisión Central de la siguiente forma: "La comision repite, que no ha sido ni es su animo desechar ninguna clase de obras por despreciables que sean; pero de esto á conservar, formar indices, ocupar lugar y hacer dispendios con una multitud de egemplares de una misma obra que no puede proporcionar ninguna utilidad, ni tener otra salida que para emboltorios en las tiendas y boticas, hay una inmensa diferencia. Lo que su enagenacion produgese, podria invertirse en la encuadernacion de obras de merito que indispensablemente lo necesitan, y en la compra de otras que en vano se buscan en las bibliotecas de los conventos suprimidos. Nada se ve en ellas de economia politica, historia natural, matematicas, agricultura, etc. etc. [...]" (ARABASF, leg. 46-5/2). 
Para finalizar, en relación a los libros que no ingresaron en las bibliotecas públicas, conviene apuntar ciertos aspectos. El primero de ellos es la ocultación de libros por parte de los religiosos de los conventos y monasterios. Podían ser escondidos en el mismo edificio (se encontraron volúmenes entre los tabiques o enterrados en las cuadras) o en el exterior. Generalmente los libros escondidos se deterioraban aún más rápido que los que estaban a cargo del Estado, lo que demostraba o bien falta de previsión o bien un alto grado de rencor por parte de los responsables de dichas ocultaciones, o consideraban que la exclaustración era una medida transitoria que pronto se desharía, como ya había ocurrido en el pasado, por lo que los libros no iban a pasar mucho tiempo en los emplazamientos escogidos; también podrían haber preferido que los libros se destruyesen antes de ser nacionalizados dada la elección de los escondites, ya que bajo el estiércol de una cuadra o en una húmeda cueva no podrían conservarse en buenas condiciones durante mucho tiempo. ${ }^{25}$

El segundo aspecto a tratar es el robo. Éste se llevó a cabo inmediatamente después de la exclaustración por responsables corruptos del proceso o por personas independientes a éste pero que conocían la existencia de obras de valor en las bibliotecas y accedieron a ellas (nada complicado, ya que los edificios no contaban, por lo general, con vigilancia) para su venta o incorporación a colecciones particulares. En los casos en los que el robo se perpetró ya pasada una gran cantidad de tiempo desde la toma de posesión, el deterioro del material hacía que su destino fuese la venta como papel viejo. Por último, la falta de medios y recursos se aprovechó para separar cantidades variables de obras durante el proceso de traslado; las que finalmente llegaban a la capital de la provincia eran incorporadas a un nuevo depósito en el que estas situaciones podían repetirse de nuevo. ${ }^{26}$

25 Ambos ejemplos corresponden al caso de Toledo, provincia en la que se encontraron dos depósitos de libros escondidos, en uno de los casos por casualidad; en el otro, gracias a la colaboración de religiosos. Los que se encontraban sepultados en el estiércol de las cuadras fueron hallados por el comprador del edificio al realizar obras. Los que estaban enterrados en una cueva se hallaron gracias a las indicaciones de dos religiosos: en ambas ocasiones los volúmenes hallados se encontraron gravemente deteriorados (ARABASF, leg. 53-1/2). En Guipúzcoa, la mayoría de los libros fueron víctima de un incendio en el caserío en el que habían sido escondidos por un jesuita al firmarse el Convenio de Vergara (AGA, Educación y Cultura, caja núm. 6.735, carpeta núm. 6.581-2).

26 En el caso de León, por ejemplo, el gobernador de la provincia indicaba el 12 de marzo de 1845 que "[...] en la movilidad continua y en el descuido de sus governantes ha pasado por todas las consecuencias de un saqueo verdadero y de un atroz y barbaro vandalismo [...]" (ARABASF, leg. 48-8/2, Asuntos de carácter general). En Gerona, el Jefe Político se excusaba ante la Comisión Central el 14 de agosto de 1842 por no haber podido averiguar el paradero de los libros sustraídos de los conventos durante la exclaustración de la siguiente forma: "[...] el largo tiempo que desde entonces ha transcurrido, sembrado ademas de trastornos y revueltas políticas, ha impedido que al dirigir posteriormente la comision sus investigaciones hacia este negocio, se encontrase objeto alguno referente a los mismos" (ARABASF, leg. 47-6/2). Finalmente, en la provincia de Pontevedra, Ventura Tien, del Gobierno Político, utilizó en una comunicación al Ministro de Gobernación con fecha 27 de enero de 1844 una expresión para reflejar el proceso de averiguación del paradero de los libros que resume la situación a nivel nacional. El Gobernador afirmaba que los libros se hallaban "[...] cubiertos todos con un velo impenetrable [...]" (ARABASF, leg. 7-6/2). 
El tercero, la destrucción de libros, e incluso de bibliotecas enteras, fue la mayor causa de pérdida del patrimonio literario y artístico obtenido por medio de la desamortización. En todas las provincias se deterioraron, en el mejor de los casos, o se destruyeron completamente, en el peor, las bibliotecas de los exconventos y exmonasterios, bien parcial, bien totalmente. Se han estudiado ejemplos de todas las opciones posibles: por negligencia, por accidente, a causa de la falta de medios, en los edificios de origen, durante el traslado, en los depósitos provinciales, en los edificios destinados a biblioteca, por efectos climáticos, a causa del polvo, la humedad, los insectos, los roedores, por la acción humana y también por su inacción. ${ }^{27}$

\section{Tipología de LAS BIBLIOTECAS PÚBLICAS EN FUNCIÓN DE LOS FONDOS Y RECURSOS DISPONIBLES}

Como anécdota previa a la explicación de los diversos tipos de bibliotecas que se crearon con los fondos disponibles (que debían estar en relación con el tipo sociedad decimonónica española), y como ejemplo aislado del uso recreativo de la biblioteca pública, valga éste en el que el Administrador de Rentas de Toledo consideraba sus visitas a la denominada en la época Biblioteca Pública Archiepiscopal una actividad de ocio, aunque este tipo de distracción no estaba al alcance de la mayoría de la población, ya que carecían de la formación de este individuo. José de Leis se quejaba a causa de la negativa del bibliotecario a proporcionarle una obra arguyendo censura de

27 En Cádiz se denunciaba el estado en el que se encontraban aproximadamente 10000 volúmenes, "[...] entre los que se cuentan muchas preciosidades literarias [que] yacen acinados á merced de animales inmundos según varias veces se tiene espuesto á la superioridad"; más adelante se exponían detalladamente las condiciones en que se hallaban los libros en ese mismo edificio: "[...] ya por el deterioro que el tiempo y el abandono causaron en el edificio, ya por el polvo que se había aglomerado, con las muchas goteras y escombros que desde los techos se desplomaban directamente sobre ellos, enterrandolos, pudriendo muchos é inutilizando crecido número [...]" (ARABASF, leg. 46-3/2, Monumentos en general). En Logroño, Eustaquio Fernández Navarrete informaba acerca de los destrozos en la Biblioteca de San Millán de la Cogolla, que había visitado personalmente: "[...] me llene de lástima y dolor a ver tirados por la hermosa sala de la biblioteca infinidad de volúmenes preciosos unos por su antigüedad y rareza, otros por la magnificencia de las ediciones, allí me informaron que los aldeanos no conociendo su merito, ni valor, quienes los an arrebatado para que sirviesen de pávulo a la lumbre, quienes, para venderlos a precio de papel viejo o sacar utilidad de los pergaminos o pastas; y como este saqueo se hace brutalmente, no ocasiona solo el mal de lo que destruye, sino el de inutilizar gran parte de lo que perdona dejando descabaladas las obras" (ARABASF, leg. 49-1/2). 
tipo religioso, ${ }^{28}$ ya que ésta había sido prohibida por la ya extinta Inquisición. $^{29}$

Además de observar un extraño, por poco frecuente, caso de función recreativa de la biblioteca pública, es de gran importancia señalar cómo el preponderante papel de la Iglesia como gestora cultural en España lastraba la evolución de las entidades educativas y formativas, dejándolas postradas ante la mayoritaria corriente ultramontana que dominaba la institución eclesiástica, fundamentalmente caduca y atrasada, de forma que la sociedad estaba imbuida de los mismos valores que eran inculcados por aquélla. ${ }^{30}$

Según Fernández Abad (2006: 101), en el siglo XIX las bibliotecas públicas pasaron de tener unas funciones de carácter religioso y moral a otras de instrucción y difusión de la cultura, realizando esta transformación a través del cambio en sus fondos. Como resultado, nacieron dos vertientes en los objetivos de formación de las bibliotecas, “[...] social-moral y profesional-técnica”.

Esta idea es interesante, ya que las bibliotecas creadas en España tenían unos fondos principalmente religiosos al proceder de las órdenes suprimidas, de forma que la evolución en las funciones de este tipo de centros en nuestro país tendría que esperar hasta que se destinaran recursos económicos para la compra de libros más modernos y adecuados a los nuevos objetivos que se estaban persiguiendo en otros países, entre los que Fernández Abad (2006) destaca Reino Unido y Estados Unidos. Escolar Sobrino (1983:

28 "Siendo mi unica diversion en los momentos de ociosidad la concurrencia á esta Biblioteca Publica Archiepiscopal, pedi en la mañana de ayer a su Bibliotecario mayor el Presvitero Dn. Pedro Hernandez la obra del Gerundio para hacer un cotejo que me ocurria con uno de sus sermones de critica que estoy arto de leer, y me la negó rotundamente saviendo que hay dos ediciones de ella, solo porque está prohivida por la extinguida Ynquisicion sacerdotal, de la que si hubiese tenido y aun conservase alguno de los permisos especiales que dava para leer libros prohividos y se lo hubiese manifestado al Presvitero Hernandez, seguramente me la hubiera franqueado con puntualidad. Señor Exmo., respeto profundamente la Religion de mis Padres y el Sacerdocio que la sirve, como el Agente mas poderoso para domesticar la ferocidad popular quando su voluntad está unida a la del Gobierno para mover concertados todos los resortes que producen el resultado; pero si en esta Generación tan atrasada la instrucción publica y los que aun son capaces de discurrir, y señaladamente los que se han consagrado al servicio del Estado, han de gemir sus luces bajo los añejos y encallecidos caprichos de un Presvitero que tal vez puede aborrecernos por su opinion divergente en el interés reciproco, se palpan consecuencias funestas de embrutecimiento que son notorias a la ilustracion y saviduria de V.E. a quien me resigno sumiso" (ABN, 0007/02).

29 Según indicaba Gil de Zárate (1995: t. 1, VI), "La losa que echó sobre nosotros la Inquisición fue tan pesada, que no hemos podido aún quitárnosla enteramente de encima: el Santo Oficio, desterrado de nuestras instituciones, no ha dejado de ejercer su maligna influencia en las costumbres; y el pensamiento lanzado por él en perniciosas vias, se resiste á entrar por las que conducen á las alturas de la civilizacion moderna".

30 Como afirma García López (2002: 129): "La sociedad del siglo XIX es una sociedad en lenta evolución donde las formas ancestrales de pensamiento y comportamiento tienen todavía un gran arraigo, la ciencia se va imponiendo a duras penas sobre la mentalidad religiosa tradicional, sobre un catolicismo alejado de la reflexión filosófica, sobre una religiosidad superficial (o en todo caso acrítica con su propia esencia)". 
324-325), por su parte, indica que en estos dos países las bibliotecas públicas fueron creadas como un "[...] instrumento de redención de las clases populares, a las que debían proporcionar un sano entretenimiento, al tiempo que las alejaban del vicio y les facilitaban la mejora de su formación laboral".

Estos argumentos también aparecieron en la formación del sistema bibliotecario liberal, con la salvedad de la inadecuación de los fondos para la consecución de dichas objetivos. En el caso estadounidense, las bibliotecas públicas podrían servir de refuerzo a la democracia, ya que la lectura y el estudio de varios puntos de vista sobre un tema contribuían a la formación de un criterio propio que facilitaría la toma de decisión a la hora de emitir un voto (Escolar Sobrino, 1983). En el caso español, aunque los principios ilustrados que, en algunas ocasiones, inspiraban la creación de bibliotecas perseguían la formación de ciudadanos informados y responsables socialmente; la visión paternalista de los centros de lectura públicos como alternativa al ocio considerado "pernicioso" era la más extendida. ${ }^{31}$ Como asevera Escolar Sobrino (1983), la biblioteca no es un fin, sino un medio para conseguir objetivos de carácter social, un "arma política".

En cuanto al estudio de la tipología bibliotecaria, estos centros se han dividido en varias categorías. Si bien es cierto que los que se han analizado como bibliotecas formadas adecuadamente adolecían de graves carencias que no han sido ignoradas a la hora de elaborar esta clasificación, se han incluido bajo esta denominación una serie de centros debido a que han sido considerados no solamente en el contexto de su época, sino también con respecto al resto de las bibliotecas; es decir, se considera que esas provincias se encargaron de la creación de centros independientes y bien formados respecto, por un lado, de los criterios que eran empleados a mediados del siglo XIX por un Estado endeudado y en guerra y, por otro, de su comparación con el resto de las provincias, en las que las carencias eran mucho más graves o en las que no se llegaron a formar bibliotecas.

En cuanto a las bibliotecas que dependían de centros de enseñanza u otras entidades, este camino fue abierto por las universidades. El hecho de que el Estado pasase de otorgar las competencias de la gestión de los bienes artísticos y literarios (de las comunidades religiosas suprimidas) de las comisiones científicas y artísticas a las universidades (en el caso de las provincias que contaban con ésta) tuvo su origen, como se apuntó anteriormente, en la

31 Esta función de la biblioteca pública tendría relación con la diferencia que señala Botrel (1996b: 275) entre la visión y el concepto del uso del libro y la lectura entre las clases medias y bajas y la alta sociedad letrada y erudita: "Le divorce entre le goût populaire est consommé [...] Autant l'indignation et les condamnations de Campomanes ou d'Iriarte vis-à-vis de leur utilisation pour l'apprentissage de la lecture que les mesures prises les «esprits éclairés» sont impuissantes à contenir -et, a fortiori, abolir- ce qui apparaît comme un véritable phénomène". 
real orden de 22 de septiembre de 1838 . Con esta medida se trataba de minimizar el impacto de problemas como que el Estado no podía hacerse cargo de los bienes conventuales, que sin el debido tratamiento se estaban deteriorando rápidamente; que los objetos artísticos y literarios ya no eran bienes de uso común de las comunidades religiosas, sino que habían pasado a formar parte del patrimonio nacional, pero la administración no podía obtener un beneficio social a partir de ellos y ni siquiera era capaz de conservarlos.

A pesar de que aparentemente la normativa era clara, en ocasiones surgieron disputas y desacuerdos respecto a la titularidad y la custodia de los libros procedentes de los conventos y monasterios suprimidos, pero el mayor problema era que a pesar de la teoría en la que la biblioteca tenía una denominación pública y estaba abierta a cualquier usuario, el hecho de estar situada en el seno de una institución que en el siglo XIX era de un marcado carácter elitista dificultaba aún más el acceso a los fondos que en las formadas independientemente. Por último, que una universidad pasase a hacerse cargo de los libros procedentes de la desamortización no garantizaba una gestión más correcta que la ejercida por las comisiones.

Más adelante continuó cediéndose la gestión de los libros procedentes de la desamortización a otros centros: en primer lugar, los institutos de secundaria fueron elementos clave en el proceso de creación de bibliotecas en los orígenes del sistema bibliotecario español, debido a que su importancia creció paulatinamente, a la vez que estos centros comenzaban a crearse en todas las provincias españolas. En el extremo opuesto se encontraban las sociedades económicas de amigos del país, entidades en declive, cada vez con menor importancia y actividad, pero que en algunas provincias se encargaron de la recolección y gestión de las bibliotecas conventuales y monacales. Por último, se encuentran las bibliotecas episcopales y arzobispales; ésta era la única opción en la que los libros procedentes de la desamortización, de marcado carácter religioso, podían ser realmente aprovechados por unos usuarios adecuados a su tipología.

Además, existe una categoría de provincias cuya gestión de los bienes literarios procedentes de los conventos y monasterios suprimidos fue deficiente o ineficaz. Se incluyen bajo esta denominación las provincias en las que no se llegó a formar una biblioteca, quedando los libros en un depósito permanente o incluso en los lugares de origen. Generalmente se denominaba "biblioteca" a estos depósitos, que en ocasiones contaban incluso con personal o alguna dotación económica, pero que no estaban abiertos al público ni contaban con medios suficientes para poder hacerlo. En ocasiones sí se formó una biblioteca, pero la dotación o los recursos eran tan escasos que no podía funcionar como tal. También se incluyen en esta categoría las provincias en 
las que se afirmaba que la biblioteca había sido creada, pero las evidencias demuestran que no era cierto.

En todo caso, son abundantes los ejemplos de mala gestión, de desinterés de las autoridades, de desorganización administrativa a todos los niveles y de problemas económicos de gravedad variable. Existen ejemplos en los que los comisionados tenían una gran voluntad y conseguían realizar avances a pesar de todas sus limitaciones; en otras ocasiones, éstos sucumbían a la inercia de la situación general y su actividad iba languideciendo paulatinamente. La situación en estas provincias, con carencias y problemas de todo tipo, marcó, en definitiva, la tónica general en la formación del sistema bibliotecario liberal.

\section{Conclusiones}

En relación con las funciones sociales de la biblioteca, se ha comprobado que para la inmensa mayoría de la sociedad decimonónica el concepto de biblioteca pública les era ajeno y dichas entidades, innecesarias. De ahí que los centros creados durante este periodo, que generalmente acabaron estando a cargo de instituciones públicas de enseñanza media y superior, tuvieran un limitado impacto resultando, por lo general, ignorados por el público potencial. Los usuarios reales eran una exigua minoría que pertenecía a una élite ilustrada de profesores, estudiantes o eruditos.

Los fondos bibliográficos disponibles no se correspondían con las funciones características de una biblioteca pública, ni siquiera si se considera la misma según la concepción dominante durante el siglo XIX en España, puesto que la temática de las obras era mayoritariamente de carácter religioso. En la normativa emitida durante el proceso de creación de estos centros se formularon una serie de objetivos que debían cumplir según la propuesta teórica liberal; sin embargo, los medios disponibles no eran los adecuados para alcanzarlos.

Se han identificado las siguientes funciones para la biblioteca pública decimonónica: depósitos del patrimonio cultural, control social, instrucción pública y formación profesional y servicio a la comunidad de docentes y estudiantes. Se concluye que realmente las bibliotecas públicas provinciales sirvieron como depósitos del patrimonio bibliográfico al servicio de centros de enseñanza media y universidades; de esta forma, el sistema bibliotecario resultante no respondía ni a una necesidad social latente entre la mayoría de la población, ni a los requerimientos de la minoría ilustrada que buscaba que las bibliotecas coadyuvasen a la formación profesional de las capas populares desde un prisma paternalista o que sirviesen como instrumentos de control social mediante la regulación del acceso a las posibles lecturas. 
El resultado estuvo realmente muy alejado de los objetivos planteados, tanto inicialmente como en su reformulación durante el periodo estudiado. Además, tampoco se aprovechó el potencial de la enorme riqueza del recién adquirido patrimonio literario y artístico. La tipología bibliotecaria generada no fue producto de una planificación previa, sino la consecuencia de la diferente gestión que cada provincia llevó a cabo al enfrentarse a diversas situaciones que acaecieron durante el proceso.

\section{FuENTES}

ABN, 0007/02, Comunicación de 7 de junio de 1810 de José de Leis, Administrador de Rentas de Toledo, al Ministro de Interior ABN, 0097/12, Secretaría general H01-Actividades Bibliotecarias 04 ABN, 0106/03, Oficio de 23 de agosto de 1843 de Eugenio de Tapia, bibliotecario de la Biblioteca Nacional al Ministro de Gobernación

ABN, 0448/8, Secretaría general H01-Incorporaciones y adquisiciones 05

AGA, Educación y Cultura, caja núm. 6.735, carpeta núm. 6.581-2, Oficio con fecha 10 de marzo de 1849 del Rector de la Universidad de Zaragoza al Ministro de Instrucción Pública

AGA, Educación y Cultura, caja núm. 6.738, carpeta núm. 6.584-80, Oficio con fecha 8 de julio de 1848 de Dimas Corral, director del Instituto de Secundaria al Director General de Instrucción Pública AGA, Educación y Cultura, caja núm. 6.739, carpeta núm. 6.585-37, Oficio con fecha 11 de diciembre de 1868 del Rector de la Universidad de Salamanca al Ministro de Fomento

AGA, Educación y Cultura, caja núm. 6.739, carpeta núm. 6.585-4

ARABASF, leg. 3/2, Monumentos en general

ARABASF, leg. 4/2, Asuntos de carácter general

ARABASF, leg. 7-5/2, Museo-Biblioteca

ARABASF, leg. 7-6/2, Museo-Biblioteca

ARABASF, leg. 44-1/2, Museo-Biblioteca, Informe evacuado con fecha 16 de junio de 1847 por la Comisión Central al Ministro de Comercio

ARABASF, leg. 44-4/2, Monumentos en general

ARABASF, leg. 44-5/2, Monumentos en general, Presupuesto elaborado por la Comisión Provincial y enviado a la Central el 11 de febrero de 1845

ARABASF, leg. 44-7/2, Objetos procedentes de conventos suprimidos

ARABASF, leg. 45-1/2, Museo-Biblioteca

ARABASF, leg. 46-3/2, Museo-Biblioteca

ARABASF, leg. 46-3/2, Monumentos en general, 20 de junio de 1844

ARABASF, leg. 46-5/2, Museo-Biblioteca 
ARABASF, leg. 46-7/2, Museo-Biblioteca, Actas de la sesión con fecha 9 de julio de 1843 de la Junta de Gobierno Provisional

ARABASF, leg. 47-6/2, Museo-Biblioteca

ARABASF, leg. 48-3/2, Museo-Biblioteca

ARABASF, leg. 48-8/2, Museo-Biblioteca

ARABASF, leg. 48-8/2, Asuntos de carácter general

ARABASF, leg. 49-1/2, Museo-Biblioteca

ARABASF, leg. 49-7/2, Asuntos de carácter general y administrativo. Atribuciones. Reglamentos

ARABASF, leg. 50-1/2, Museo-Biblioteca

ARABASF, leg. 50-1/2, Personal-Organización de la Comisión, Oficio de 27 de julio de 1844 remitido por Juan Ruiz, el presidente, y Pedro Armada Valdés, vocal secretario, al Presidente de la Central informando acerca de su constitución

ARABASF, leg. 50-4/2, Museo-Biblioteca, Comunicación de 29 de marzo de 1845 de la Comisión Provincial a la Central

ARABASF, leg. 52-4/2, Museo-Biblioteca, Asuntos de carácter general para Segovia

ARABASF, leg. 52-5/2, Museo-Biblioteca

ARABASF, leg. 53-1/2, Museo-Biblioteca

ARABASF, leg. 53-4/2, Objetos procedentes de conventos suprimidos

ARABASF, leg. 54-1/2, Museo-Biblioteca

ARABASF, leg. 54-7/2, Museo-Biblioteca, Respuesta de Laureano de Arrieta, del Gobierno Político, a la circular de 14 de enero de 1844

ARABASF, leg. 54-4/2, Museo-Biblioteca

ARABASF, leg. 55-2/2, Real orden de 29 de julio de 1835 dirigida a los gobernadores civiles mandando que se crearan comisiones en cada provincia para inventariar y recoger los bienes nacionales y estableciendo los procedimientos de su actuación

ARABASF, leg. 55-5/2

ARABASF, leg. 7-5/2, Museo-Biblioteca

ARABASF, leg. 7-6/2, Museo-Biblioteca

ARABASF, sig. F7881, Discurso pronunciado en el solemne acto de la apertura de la Biblioteca Provincial y del Instituto de Segunda Enseñanza de las Baleares, que tuvo lugar el día 1. ${ }^{\circ}$ de octubre de 1847; por el muy ilustre señor D. Joaquin Maximiliano Gibert [...] gefe superior político de la misma provincia. Palma: imprenta á cargo de D. Juan Guasp, 1847

Baulo, Sylvie. 2003. "La producción por entregas y las colecciones semanales”, en Víctor Infantes et al. (dirs.), Historia de la edición y de la lectura en España (1472-1914). Madrid: Fundación Germán Sánchez Ruipérez. 581-590.

Bello, Josefina. 1997. Frailes, intendentes y politicos. Los bienes nacionales 1835-1850. Madrid: Taurus. 
Botrel, Jean-François. 1993. Libros, prensa y lectura en la España del siglo XIX. Madrid: Fundación Germán Sánchez Ruipérez, Pirámide 1996a. "Los nuevos lectores en la España del siglo XIX", Siglo diecinueve (Literatura hispánica) 2: 47-64.

1996b. "La littérature de cordel en Espagne. Essai de sythèse", en Roger Chartier y Hans-Jürgen Lüsebrink, Colportage et lecture populaire: Imprimés de large circulation en Europe XVIE-XIXE siècles. Actes du colloque des 21-24 avril 1991. Wolfenbüttel. París: IMEC Éditions; Éditions de la Maison des Sciences de l'Homme, 271-281.

Burón Castro, Taurino. 1995. "Los inventarios de desamortización: recurso para el seguimiento del patrimonio documental", Boletín de la ANABAD XLV (4): 25-50.

Carr, Raymond. 1982. España 1808-1975. Barcelona: Ariel.

Carrillo, Víctor. 1974. "Radiografía de una colección de novelas a mediados del siglo XIX («El Novelista Universal», de la Sociedad Literaria)”, en Manuel Tuñón de Lara y Jean-François Botrel (eds.), Movimiento obrero, política y literatura en la España contemporánea. Madrid: Cuadernos para el diálogo, 159-177.

Colección de órdenes generales y especiales relativas á los diferentes ramos de la Instrucción pública secundaria y superior desde $1^{\circ}$ de enero de 1834 hasta fin de Junio de 1847. 1847. T. II. Madrid: s.n. [Imprenta Nacional].

Cruz Solís, Antonio de la. 2008. "Bibliotecas y educación básica: los inicios de una relación imprescindible”, Documentación de las ciencias de la información 31: 129-160.

Darnton, Robert. 1994. "Historia de la lectura", en Peter Burke (ed.), Formas de hacer historia. Madrid: Alianza, 177-208.

Escolar Sobrino, Hipólito. 1983. "Lectura y política bibliotecaria”, en Fernando Lázaro Carreter (coord.), La cultura del libro. Madrid: Fundación Germán Sánchez Ruipérez, 321-334.

Fernández Abad, Francisco Javier. 2006. "Evolución histórica de la función social de las bibliotecas públicas”, Revista General de Información y Documentación 16 (2): 93-110.

Fernández Prado, Emiliano. 1991. La política cultural, qué es y para qué sirve. Gijón: Trea.

Fernández, Pura. 2003. "Lecturas instructivas y útiles”, en Víctor Infantes et al. (dirs.), Historia de la edición y de la lectura en España (1472-1914). Madrid: Fundación Germán Sánchez Ruipérez, 672679.

Ferrer, José María. 2012. La monarquía isabelina 1833-1868: crónica ilustrada de Madrid. Madrid: Ediciones La Librería.

Fontana, Josep. 1973. La crisis del Antiguo Régimen, 1808-1833. Barcelona: Ariel.

Fontbona, Francesc. 2003. "Texto e imagen”, en Víctor Infantes et al. (dirs.), Historia de la edición y de la lectura en España (1472-1914). Madrid: Fundación Germán Sánchez Ruipérez, 705-710. 
García López, Genaro Luis. 2002. "Nacimiento y desarrollo de la Biblioteca Pública de Cuenca durante el siglo XIX", Archivo conquense 5: 111-145.

2003. Libros para no leer: el nacimiento de la política documental en España. Gijón: Trea.

2007. "Evolución histórica de los conceptos de biblioteca pública, sistema de bibliotecas y política bibliotecaria", Códice, Revista de la Facultad de Sistemas de Información y Documentación 3 (2): 9-20.

Gil de Zárate, Antonio. 1995. De la Instrucción Pública en España. Oviedo: Pentalfa.

Hernández Díaz, José María. 1986. "Los alumnos de segunda enseñanza en el siglo XIX”, Historia de la Educación. Revista interuniversitaria $5: 251-273$.

_ 1992. "Alfabetización y sociedad en la revolución liberal española", en Leer y escribir en España: doscientos años de alfabetización. Salamanca: Fundación Germán Sánchez Ruipérez; Madrid: Pirámide, 69-89.

Hernández Hernández, Francisca. 2002. El patrimonio cultural: la memoria recuperada. Gijón: Trea.

IFLA, Sección de Bibliotecas Públicas. 2001. Directrices IFLA/Unesco para el desarrollo del servicio de bibliotecas públicas, Organización de las Naciones Unidas para la Educación, la Ciencia y la Cultura. Federación Internacional de Bibliotecarios y Bibliotecas. Sección de bibliotecas. Disponible en unesdoc.unesco.org/images/0012/ 001246/124654s.pdf [Fecha de consulta: 21 de noviembre de 2012].

Infantes, Víctor. 1997. "Las ausencias en los inventarios de libros y bibliotecas”, Bulletin Hispanique 1: 281-292.

Lopez, François. 1998. "Las malas lecturas. Apuntes para una historia de lo novelesco", Bulletin Hispanique 2: 475-514.

Martínez Martín, Jesús A. 2003. "La lectura irreverente o la educación descuidada. Un episodio de historia cultural”, Cuadernos de Historia Contemporánea núm. extraordinario: 137-144.

Muñoz Feliu, Miguel C. 2006. "Liberalismo, desamortización y política bibliotecaria. El caso valenciano", Anales de documentación 9: 133-141.

Paz, Julián. 1913. "Los archivos y las bibliotecas de Valencia en 1842", Revista de Archivos, Bibliotecas y Museos XVII (11-12): 353-373.

Peset, Mariano y J. Luis Peset. 1974. La Universidad española (siglos XVIII y XIX). Despotismo ilustrado y revolución liberal. Madrid: Tecnos.

Ponce, Aníbal. 1987. Educación y lucha de clases. Madrid: Akal.

Puelles Benítez, Manuel de. 1999. Educación e ideología en la España contemporánea. Madrid: Tecnos.

Romero Tobar, Leonardo. 1976. "Un gabinete de lectura en el Madrid del siglo XIX", en Anales del Instituto de Estudios Madrileños, t. XII, 205-211. 
Ruiz Berrio, Julio. 1970. Política escolar de España en el siglo XIX (1808-1833). Madrid: Consejo Superior de Investigaciones Científicas.

San Segundo Manuel, Rosa. 1996. Sistemas de organización del conocimiento. La organización del conocimiento en las bibliotecas españolas. Madrid: Universidad Carlos III de Madrid, Boletín Oficial del Estado.

Trías, Juan J. y Antonio Elorza. 1975. Federalismo y reforma social en España (1840-1870). Madrid: Seminarios y Ediciones.

Viñao Frago, Antonio. 1991. "Sistema educativo nacional e ilustración: un análisis comparativo de la política educativa ilustrada", en Sociedad, cultura y educación. Homenaje a Carlos Lerena Alesón. Madrid: Universidad Complutense, CIDE, 283-313.

Wittmann, Reinhard. 2011. “¿Hubo una revolución en la lectura a finales del siglo XVIII?”, en Guglielmo Cavallo y Roger Chartier (dirs.), Historia de la lectura en el mundo occidental. Madrid: Santillana, 353-385. 
Anexo 1

Provincias que enviaron inventarios a la comisión central, fecha en que lo hicieron y volúmenes inventariados

\begin{tabular}{|l|l|c|}
\hline \multicolumn{1}{|c|}{ Provincia } & \multicolumn{1}{|c|}{ Fecha de envío de inventarios } & Núm. De volúmenes \\
\hline Álava & 26 de junio de 1846 & 951 \\
\hline Albacete & 23 de julio de 1846 & 1259 \\
\hline Almería & 22 de [octubre 0 diciembre] de 1845 y 22 de junio de 1846 & 1358 \\
\hline Badajoz & 15 de junio de 1846 & 925 \\
\hline Ciudad Real & 3 de julio de 1846 & 165 \\
\hline Guadalajara & 16 de marzo de 1846 & 1261 \\
\hline Huesca & 22 de junio de 1846 & 8226 \\
\hline León & 4 de julio de 1846 & 2832 \\
\hline Logroño & 2 de julio de 1846 & 862 \\
\hline Oviedo & 9 de octubre de 1845 & 44 \\
\hline Palencia & 3 de [junio 0 julio] de 1846 & 772 \\
\hline Santander & 9 de julio de 1845 & 2858 \\
\hline Soria & 12 de noviembre de 1845 & 1035 \\
\hline Vizcaya & 11 de julio de 1846 & 4214 \\
\hline Total & & 26762 \\
\hline
\end{tabular}

Fuente: ARABASF, leg. 94-7/2, Circulares y disposiciones generales. Interrogatorios

Para citar este artículo:

García López, Genaro Luis. 2016. "El origen del sistema bibliotecario español: características y utilidad de los fondos bibliográficos que conformaron las primeras bibliotecas públicas en el segundo tercio del siglo XIX." Investigación Bibliotecológica: Archivonomía, Bibliotecología e Información 69: 231-262. http://dx.doi.org/10.10 16/j.ibbai.2016.04.019 